\title{
Art markets in crisis: how personal bonds and market subcultures mediate the effects of COVID-19
}

\author{
Larissa Buchholz ${ }^{1} \cdot$ Gary Alan Fine ${ }^{2} \cdot$ Hannah Wohl ${ }^{3}$
}

Published online: 7 October 2020

(c) Springer Nature Limited 2020

\begin{abstract}
We examine how the contemporary art market has changed as a result of the disruptions caused by the novel coronavirus. Based on interviews with artists, collectors, a dealer, and an auction house executive, we argue that the decline of face-to-face interaction, previously essential to art market transactions, has placed strain on each corner of the community. In the absence of physical co-presence with the artworks and art world actors, participants struggle to evaluate and appreciate artworks, make new social ties, develop trust, and experience a shared sense of pleasure and collective effervescence. These challenges especially impact the primary gallery market, where participants emphasize a communal commitment to art above instrumental speculation, which is more accepted in the secondary auction market. We find a transition to distant online communication, but the likelihood of this continuing after the lockdowns end and the virus dissipates varies according to the subcultures of these market segments.
\end{abstract}

Keywords Art market · Markets · Interaction · COVID · Online · Globalization

Larissa Buchholz, Gary Alan Fine, and Hannah Wohl have contributed equally to the preparation of this manuscript.

Gary Alan Fine

g-fine@ northwestern.edu

Larissa Buchholz

larissa.buchholz@northwestern.edu

Hannah Wohl

hwohl@soc.ucsb.edu

1 School of Communication, Northwestern University, 2280 Campus Drive, Evanston, IL 60208, USA

2 Department of Sociology, Northwestern University, 1810 Chicago Avenue, Evanston, IL 60208, USA

3 Department of Sociology, University of California, Santa Barbara, CA 93106, USA 
An "event" as consequential, extensive, and disparate as the deaths and illnesses from the novel coronavirus cannot but alter society. Of greater sociological significance, the personal, interactional, and institutional reactions that stem from this medical trauma are bound to challenge and reshape many aspects of culture. How could it not? Erving Goffman (1981) noted that events have a "referential afterlife," providing a template for a new cultural order as they are recalled. The afterlife of COVID-19 will be lengthy, even if, like Pearl Harbor, Hiroshima, or 9/11, the remembrances may be limited to ceremonial occasions (Saito 2006). Like Harpers Ferry, Fort Sumter, Gettysburg, Ford's Theater, and Appomattox, the histories of trauma or national triumph are available to be unearthed as needed.

In this essay, we explore how the global pandemic has affected the production, distribution, and consumption of culture with regard to the contemporary art market. In this, we operate in the intellectual space that connects a relational model of the local culture of art worlds (Becker 1982) and the strong culture program of symbolic meaning structures (Alexander 2006). This perspective treats the art market as a set of subcultures with shared meanings that develop through interactions and manifest in particular networks (Velthuis 2005). Even in global markets, the establishment of norms and trust rests on local cultures and shared conventions.

The COVID-19 crisis led to stay-at-home orders and the closure of physical spaces in which interactions flower. Our puzzle is to explain how art market participants navigate the disruptions of the crisis in the absence of face-to-face encounters while maintaining the emotional satisfactions of the community in light of these new practices and relations. Every market has been dramatically affected by the COVID-19 crisis and related lockdowns. Yet, the contemporary art market depends on the affective contours of face-to-face interaction and direct engagement with consecrated artworks. Galleries exhibit artists' work in brick and mortar spaces, often situated in artistic neighborhoods, and showcase them in global art fairs. Collectors and other appreciators attend gallery openings and fairs not only to view art, but also to enjoy socializing, gossiping, and engaging within friendship networks and leisure tribes. Collectors also purchase works from art auctions that offer more price transparency, but function as secondary markets to resell works by more established artists.

To understand the impact of current changes in a market that is so reliant on inperson operations, we interviewed six figures in several domains of the contemporary art market in the United States: (1) an emerging artist, (2) an established artist with gallery representation, (3) a young collector, (4) an established collector, (5) a gallery owner, and (6) an auction house chair. We conducted these in May 2020, during a period in which most businesses were closed and lockdowns were in place in many of the states in which the art market was most prominent, notably New York and Illinois. We recognize that the effects of COVID-19 on the art world altered throughout 2020, and there is a need for an analysis after the pandemic and its reverberations are judged past. Each interview was tape-recorded and lasted over an hour. From each interview, we created a several page vignette describing the changes that COVID-19 has brought to their practices and how they relate to art and distant others (all but one of these vignettes are available upon request). To be sure, these interviews cannot claim to be representative. When available, we supplemented 
our findings with secondary sources, contextualizing them with broader art market dynamics. By looking at art producers, intermediaries, and consumers, we also explored variations among types of market participants.

We argue that the experience and effects of the crisis are mediated by the norms regarding in-person engagement with the contemporary art market. Experiences of co-presence with auratic works are critical, as participants are supposed to value art aesthetically and because every work is unique (Karpik 2010; Velthuis 2005). Face-to-face interactions are also central because participants expect experiences of collective effervescence from socializing, expressing communal commitments to art, and engaging in the performance of purchasing. Furthermore, face-to-face interactions are critical for developing informal relationships based upon trust, given ambiguous pricing. As most market interactions have moved online, bonds of trust facilitate modes of coping with COVID-19 disruptions. They also reveal a strong desire by participants to reduce uncertainties by connecting with close collaborators as they produce, value, and transfer objects remotely. Yet despite a desire for stability in interaction orders, now operating at a distance, COVID-19 prompted remarkable changes in the auction segment toward a more digitized market sphere, especially when compared with the gallery segment. These changes are facilitated by the auction house's capacity to offer trust markers beyond face-to-face bonds as well as distinctive representations of art as a financial asset, rather than, more traditionally, an auratic object that requires personal inspection.

\section{The artists}

While the two artists we interviewed are at different stages in their careers, both continue to produce art works during the pandemic. Chicago-based emerging artist Angela Lopez graduated with an MFA degree from the Art Theory and Practice program at Northwestern University in 2015. As a newly minted artist who works on a small-scale, she does not rent other space and continues to make as much work in her home studio as previously, producing paintings and sculptures. For New York City-based established artist B Wurtz, the pandemic has spurred his production, as he no longer has the city's many cultural amenities to distract him. Much of his work involves the use of everyday found objects, from socks to plastic grocery bags, from which he makes modestly sized sculptures. This process of production does not require studio assistants. He has stockpiled found objects and acquired material at grocery stores. The pandemic has made his practice feel more germane: "Food, clothing, shelter: the basics of life. I thought, "What could be more relevant right now?'" While Wurtz's and Lopez's practices have remained relatively stable, other artists report more changes. Artists who deal with political themes and street artists, like Banksy, have explicitly responded to the pandemic in their work (Belcove 2020). Prominent artists with large studios and numerous assistants report that they made changes that are more drastic not just in their themes, but also in their production process. They adapted by delivering materials to their assistants' homes or by pausing production (Cohen 2020). 
While some artists, like Wurtz and Lopez, work independently, the process of exhibiting work publicly and building connections within the art world inevitably involves interaction. Lopez, a mother of a three-year-old son, finds that she has been able to "attend" more evening events, even though these events are now on Zoom and other platforms, because she does not need to leave her son. Before COVID-19, she founded an artist-led collaborative event series for emerging artists who are also mothers, for which she has curated shows and organized events. The group met faceto-face, but now conducts their gatherings, like many artistic groups, on the Zoom platform. While this was not as satisfying or frequent, it provided a continuing connection among these artist-mothers as they struggled with their new situations. The last exhibition of their material objects ended in February 2020; future shows have been postponed, now into 2021 given the conditions of COVID-19. But their support and trusting relations remain.

As a more established artist, Wurtz's schedule of exhibitions was upended. He had shipped work to a gallery in Madrid for an April 2020 opening, only to learn that this exhibition was postponed. He believed that the gallery would safeguard his work. A September exhibition was canceled, but he trusts that the gallery will mount the show later. His sales have not entirely vanished, and he believes that he maintains the support of committed collectors. Wurtz has moved online, not only with his exhibitions, but with his connections. The virus has altered his sociality. "I finally broke down and joined Instagram," he reports. He learns from the work of others by following artists and galleries, building relations at a distance. However, the network of artists and galleries that Wurtz interacts with online largely consists of pre-existing social ties, although these online platforms provide the opportunity to rekindle quiescent social connections. In addition, mingling digitally does not establish tight intimacy. He feels that he cannot fully appreciate art that he views online: "I don't think we want to stay with the digital world, because that's not what art is. It is about the physicality." For Wurtz, art is best appreciated in person. Yet, in a sense, the materiality is also the sociality. The art world depends on being there. For artists, online exhibitions and social media platforms offer opportunities to circulate their work and engage with their peers; however, artists find these interactions aesthetically lacking in that they do not get the same fulfillment from viewing artwork online. Socially, they also feel unfulfilled, as they do not experience the collective effervescence - the powerful excitement—of socializing with like-minded peers nor can they develop new connections remotely.

\section{The collectors}

For collectors, trust is essential. While purchasing art is an economic transaction, personal ties are crucial, particularly at the higher end of collecting (Moulin 1987; Velthuis 2005). An older collector (who asked that his name and details not be used) explained that he only buys from dealers with whom he has established relations and is skeptical of digital art purchases. He trusts that he will receive the work and that the work is authentic, while dealers trust that he will pay and return it in the same condition if it does not suit him. 
This view is distinguished from that of Megan Green, a younger New York Citybased collector, now in her 30s, who is currently engaging with the art world online. Green has been visiting GalleryPlatform.LA, an initiative co-launched by Jeffrey Deitch to showcase exhibitions from ten Los Angeles-based galleries each week as well as online viewing rooms for art fairs. She notes, "[These platforms] might have some real staying power, because you can't be everywhere, so I think there is a really nice bridge between the physical and digital world." While she would rather view art in person, online platforms enhance her engagement with the art world when this is not possible. In meetings with young collectors who donate to the American Friends of the Israel Museum, she argued that the group should plan virtual studio visits and visits to collectors' homes not easily accessible in person: "I don't want to see someone's collection I can go to, but show me something in Dallas, where I never am." For Green, digital platforms are not a replacement for the physical world, but a valuable supplement.

Green finds the increased transparency in pricing on some online platforms a major benefit. Many online viewing rooms at art fairs now list prices, rarely posted during in-person fairs or gallery exhibitions. Given that the art market is unregulated, Green finds more pricing information. Of course, these prices may not be what are offered to best customers, but it is better than having no gauge as a gallery whose posted prices are excessive will lose trust. Green feels that the increase in pricing transparency benefits new collectors, who lack trusting relationships with dealers. The move to online platforms may encourage younger collectors, who report more willingness to purchase works online than those older (Hiscox 2019).

However, Green states that if the lockdown was permanent, it would "severely stifle" her collecting. Since the start of the pandemic, she has only purchased two small works, both for coronavirus relief benefits. Despite the openness that online platforms offer, Green finds that she searches for artists and galleries with which she is already familiar, whereas in-person fairs offer the possibility to browse hundreds of galleries' booths and make unexpected connections: "[In a fair], I am going to see things even if I didn't intend to see them. When you are put in an online platform, I found that I was looking at things that I knew I wanted to see or going to galleries I already know... whereas I wasn't clicking on a gallery I didn't know." Green misses wandering the fair with her friends. In this belief, there is no generation gap. When she showed Frieze's [an important art show] online viewing rooms to her father, "He just didn't have any interest, and he would have normally gone... It kind of loses some of the allure of the environment, and for art, environment is so important. I think you lose a lot of that virtually." For collectors, online interactions, devoid of face-to-face encounters, lack the emotional energy that derives from serendipitous experiences with friends.

A further constraint relates to the physicality of works themselves: "I can think of a ceramicist I've been looking at, and I was like, 'Oh, I'd like to buy one of his pieces,' because I saw them online, and then I thought to myself... 'I'd rather go see them in person before I buy them, and I can't do that, so I'll just wait.' ... If this was permanent, it would severely stifle my collecting." Green occasionally buys online, but only when she has seen similar works by that artist in person. Otherwise, she feels "completely blind." During the pandemic, she avoids the work of artists with 
whom she is unfamiliar. As art is not an "essential" good, collectors feel that they can pause their collecting. While online platforms may offer price transparency and the ability to transport oneself digitally, in practice collectors do not travel everywhere virtually, but reinforce existing social ties, and reduce their engagement with the art market. This results from the limited way in which they use online platforms, their desire to evaluate unique works in person, their need for trusting relationships with dealers, and the lack of stimulating collective effervescence from online interactions.

\section{The gallerist}

Mediators in the art market have experienced COVID-19 as a major disruption lacking historical precedent. With the shutdown of gallery spaces, art fairs, and live auctions, they lost their personal means to engage audiences. While the contemporary art market has long resisted online sales (Horowitz 2012; Khaire 2015), mediators had to leverage technology to keep business alive during the COVID-19 crisis. Yet the change toward the digital has not played out consistently among galleries and auction houses. The reasons for this lay also in their different market subcultures, particularly the extent to which transactions depend on personalized trust relations and the direct appreciation of art.

As key gatekeepers in the art world, gallerists promote artists to both cultural institutions and collectors (Becker 1982). Friedrich Petzel is a successful New York gallerist who opened his "space" in 1994 in what was then New York's primary gallery neighborhood, SoHo. His original purpose was artistic: "I wouldn't have called myself an entrepreneur," he confides, "more a 'fan' of contemporary art" (Cappelletti and Meris 2013). Several artists that Petzel has championed have become recognized by museums and major buyers. Consistent with the decline of SoHo, the gallery now is located in Chelsea and the Upper East Side, and operates a joint venture in Berlin. Petzel claims that he focuses on building artistic careers rather than merely selling works for profit, reflecting the anti-commercial culture that typifies the primary gallery market (Velthuis 2005; Bourdieu 1993). He reports, "The entire thing is bigger now... but it remains a gallery built with artists and for artists." Perhaps this seems overly romantic, but it is consistent with the narratives of many gallerists.

Before the coronavirus outbreak, Petzel's days involved numerous face-to-face meetings. Because he promotes artists internationally, he traveled extensively. He had planned trips to Rome, Hong Kong, and Germany. Personal interactions were critical. He had to see artworks and exhibition spaces, discuss budgets, and win the trust of collectors. "If someone is going to spend up to a million bucks with me," he says, "they want to know that I am not a crook." Presumably, a direct meeting permits this assessment. Face-to-face encounters also allow Petzel to screen buyers and create affiliative bonds. He shuns speculators who "flip" works at auctions, which can destabilize artistic careers: "I want to make sure with the handshake... that this thing does not show up at the next auction house." "Building trust," he adds, is "the basis of what we do." His emphasis resonates with the "logic of a moral economy" 
that dominates the primary market in which "meaningful goods are transacted on the basis of personal long-term relationships" (Fillitz 2014; Velthuis 2005).

In March, Petzel's gallery closed abruptly. He now coordinates his team through "laborious" online conferences. He has postponed exhibitions, dealt with canceled art fairs, and worked on online outreach. Beyond navigating such logistical challenges, Petzel connects with his artists on Zoom. However, those interactions feel different in building relations from his multiple studio visits. He notes,

I can't touch the artworks, the sense of humor and the sparks that fly when you are in someone's studio is gone.... On Zoom, each one of us just wants to finish this as fast as possible. But when we are in the studio, it usually ends with a few beers or a funny conversation.... We are a very funny tribe that is very much into this conviviality, this kind of gossiping.... With Zoom, it is now down to the basics. Let's agree to do this and agree to that, it is more goal-oriented.

Virtual meetings seem a poor substitute for cultivating the "traditional sense of community, trust, curiosity," says Petzel, highlighting how he is experiencing the crisis through the prism of the market's moral economy, where close relationships between dealers and artists are crucial (Velthuis 2005). These bonds are built on beliefs in shared commitments to art, experienced through frequent informal and intimate interactions.

Connecting with collectors is important to Petzel as well. Shortly after the shutdown, he called long-term clients to "find out how they are doing." Yet with the absence of face-to-face meetings, the gallery also had to develop digital ties. In November 2019, the staff had already begun working on an online platform, but COVID-19 forced it to accelerate, creating new forms of symbolic production (Alexander 2004). The gallery has launched artist videos on Instagram, introduced curated online exhibitions, and distributed newsletters. None contains open advertising for works or posted prices, but a button says "Inquire." This allows Petzel to "fish out" speculators, consistent with the non-commercial culture of his gallery segment. The market norms inform the gallerist's digital extension, even if it frustrates collectors like Megan, who hopes that the market's online conversion brings more price transparency. ${ }^{1}$

The gallery's online initiatives have supported sales, but at lower price points and Petzel lost substantial revenue within the first weeks. "It doesn't keep my doors necessarily open, but it helps the artists to get through it," he notes. A broader survey finds that nearly 200 US galleries reported a projected average loss of 73 percent for the first quarter (Kinsella 2020). Reaching collectors is difficult, not only because of the pandemic's large-scale disruption, but also because collectors are bombarded from all sides. A major collector, he estimates, receives up to 200 online offers a day. In line with the view of traditional collectors, Petzel notes that the internet has

\footnotetext{
1 Joining Sotheby's new online "Gallery Network" platform, Petzel posts prices on this platform openly, however. In this secondary market environment, his goal is to sell single works by established artists, not protecting the ongoing careers of his own roaster of artists.
} 
never been "a hugely popular way of looking at art," unable to replicate art's symbolic aura. As Petzel explains, "people that got into this in the first place... desire that type of interaction," and that is a key reason why the gallery market has long been impervious to online sales.

The desire for personal, even emotional, connection might explain why most of Petzel's online buyers during the crisis come from the gallery's social orbit. They are trusted collectors who are already familiar with the artists' work and support the gallery's program. Petzel's experiences mirror those of other dealers (Spiegler 2020). In the "moral economy" of the primary market, the leap into a distant digital sphere has not so much generated new relations, but has reinforced trusting bonds. Because of the centrality of these relations for his gallery, Petzel does not expect that the internet will dramatically change how he operates once the pandemic is over. Artists, dealers, and collectors wish to appreciate artworks in person once again and experience their shared commitment to art through community. The rituals at openings, dinners, and even handshakes matter.

\section{The auction chair}

Moving from the gallery to the auction world, the dynamics of transitioning online and interacting at a distance have evolved differently. Auction houses are central to the secondary art market. They focus on the profitable resale of works by established artists and artists whose work promises short-term commercial gains. Lisa Dennison is chair of the Americas at Sotheby's, one of the world's most powerful auction houses. Her responsibilities include "international business development." This means that she builds relationships with top clients. Like Petzel, she stresses the development of trust through face-to-face interactions. Before COVID-19 she also traveled extensively. In addition to attending auctions, fairs, and exhibition openings, she regularly visited private collections. Providing what she calls a "high touch" personal experience for prized clients is at the heart of stimulating expensive purchases and winning lucrative consignments. Just prior to the lockdown, Dennison had traveled across the United States to "win property" for this year's spring auctions. Her engagement paid off; she secured works from the Anderson Collection, valued at $\$ 55$ million.

With the pandemic's sudden lockdown, Dennison finds travel restrictions especially disruptive. She now must interact remotely for private sales, online auctions, sourcing work, and doing valuation. While some collectors have lost interest, she aims to replicate her "high touch" approach digitally, "making the outreach very personalized." As Dennison confronts her limits, she recognizes how meaningful the bonds she created before COVID-19 have become,

Because I have spent so much time building relationships and trust... an email, a phone call, a Zoom call now means something. So, we can commiserate about the difficulties of this time, we can talk about how the value of artworks might have changed... we can talk about what opportunities are on the horizon both for selling and buying, and we have that rapport. 


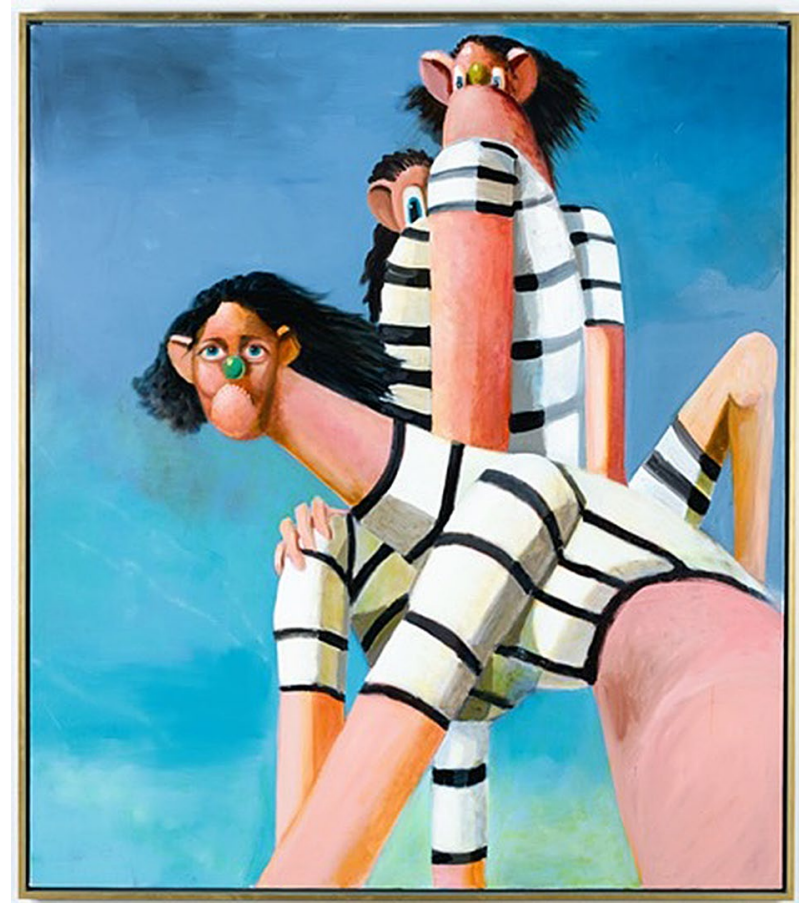

Fig. 1 George Condo, Antipodal Reunion, 2005. Sold for $£ 1,035,000$ (\$1,299,753). Courtesy Sotheby’s

Existing relations and trust help Dennison to stay engaged, even if markets are truncated.

Yet private sales are not sufficient to mitigate COVID-19's disruption. As inperson auctions were postponed, a task force that Dennison joined strategized pivoting auction sales online. The first results have been promising. By mid-May, Sotheby's (2020a, b) reached $\$ 100$ million in global online sales-a $370 \%$ increase from the same period in 2019. The house also made history with a first online price record when, on April 21, a painting by contemporary artist George Condo fetched $\$ 1,299,753$ (Fig. 1). In contrast to the gallery market, auction clients accept the online medium and, as Dennison reports, their expanded digital sales even attracted a substantial $30 \%$ of new buyers globally. This success during a crisis seems astonishing if one recalls that Sotheby's lost a disconcerting $\$ 130$ million when it briefly partnered with eBay and Amazon at the turn of the millennium, due to low online demand (Horowitz 2012).

Dennison explains that the house was well positioned for its digital jump for reasons that underline important differences with the gallery market. For one, the house had a technological head start when the lockdown happened. Capitalizing on improved technology, Sotheby's had already revived its online efforts in 2017 with more sophisticated platforms, and it also had integrated internet bids at major live auctions to accommodate a growing global bidder pool. Thus, auction clients were already beginning to trust online formats. Moreover, with an 
empire of some eighty offices worldwide, the house benefits from being a global brand. This symbolic position provides an alternative trust marker for buyers that smaller gallery enterprises cannot provide (Cappellazzo 2020).

Yet, another cultural factor sets auction houses apart from galleries: an investment logic that advanced over the last two decades. Unlike dealers, auction houses post prices publicly. That provided a commercial advantage with galleries even before COVID-19, since it lowers the threshold for novice buyers to engage with the contemporary art market through trust from increased price transparency (Coslor 2016), as Green the young collector observes. But public prices also enable the proliferation of auction indices that chart track records of artists similar to the stock market (Velthuis and Coslor 2012), attracting financially oriented buyers (Coslor 2016; Lee 2018). Dennison hints at this when she says that the positive results on online sales also have to do with the belief in art as an "alternative asset." This is the speculative buying Petzel abhors. Since auction houses are profit-driven, they are accessible to whomever makes the highest bid. This cultural structure-where buyers swarm into this more open market to snap up underpriced art as assets-helps explain why virtual auctions flourish because of the crisis. Purchasers buy low with the hope of soon selling high.

Nevertheless, online auctions currently have limits for top prices. They lack the drama of a live auction that stimulates astronomical bidding among elite clients. In March 2020, the average price for art sold online was still $\$ 6,859$ (Halperin 2020), far distant from the $\$ 60$ million that Sotheby's had estimated for a Francis Bacon painting at a live auction (Pogrebin et al. 2020). When a larger group gathers in a room to compete in acquiring work, a local culture emerges and collective effervescence builds under the guidance of a charismatic auctioneer, making all present feel communal emotion (Smith 1989; Herrero 2010). As Dennison puts it, there is a "psychology of the live auction" that stimulates high bidding: "You get cold feet with what you see happening with other participants... when someone is bidding strongly... other people feel the confidence about what they want, it is a validating experience." The top end of the art market requires the "theatre" and the "galvanizing force" of such a live event.

To cover their costs, top auction houses had to "reimagine" the format of a live auction to re-create the ritualized high drama that fuels multi-million-dollar results. In this regard, Sotheby's made a first step when it inaugurated on June 29 a globally streamed auction that spanned the world's three major auction capitals. Employees sat in rooms in New York, London and Hong Kong to accept phone bids. The auctioneer spoke from a room in London and reacted remotely to their screened actions as well as incoming online bids. Cameras in all locations were coordinated so that anyone could follow the competitive bidding spectacle. This first multi-venue globally streamed auction proved enormously successful, resulting in $\$ 363.2$ million sales. The triptych by Francis Bacon went far above its original estimate and settled for a staggering $\$ 84.6$ million after several minutes of intense bidding between someone from the United States and an online bidder from China. Sotheby's new hybrid format made auction history. As the auctioneer Oliver Barker commented: "Being on the rostrum tonight was like being at 


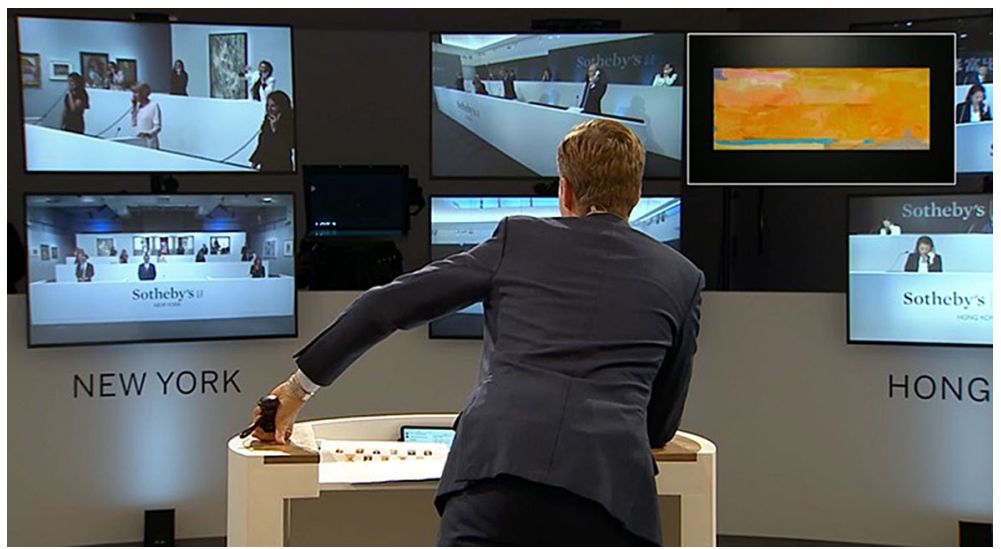

Fig. 2 The auctioneer Oliver Barker reacts to bids for a painting by Helen Frankenthaler, Screenshot of Contemporary Art Evening Auction, Sotheby's New York, June 29, 2020

Happening Now: Ginny Williams Collection Evening Sale, Contemporary Art Evening Auction, and Impressionist \& Modern Art Evening Sale

JUNE 292020 I NEW YORK

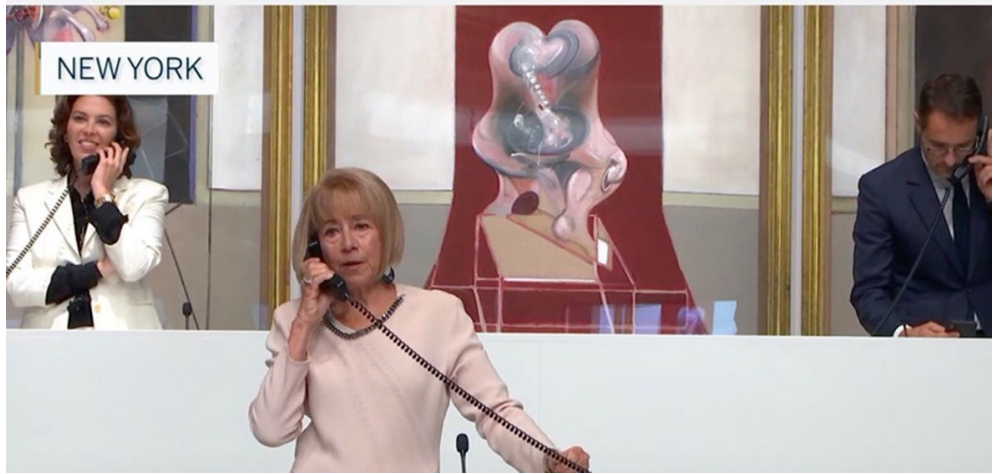

Fig. 3 Camera close-ups of specialists communicating with bidders broadcasted for the virtual live audience, screenshot of Contemporary Art Evening Auction, Sotheby's New York, June 29, 2020. In the background: Francis Bacon Triptych Inspired by the Oresteia of Aeschylus signed, titled, dated 1981 and variously inscribed on the reverse, oil on canvas, in three parts each: 198 by $147 \mathrm{~cm}$; 78 by 58 in. Estimate $\$ 60 / 80$ million Sold for $\$ 84.6$ million

Bacon: (C) The Estate of Francis Bacon. All rights reserved. / DAC, London / ARS, NY 2020

the epicentre of a cinematic production... we redefined the boundaries of what is possible." (Barker in Sotheby's 2020b) (Figs. 2, 3).

With such innovations, Dennison believes that COVID-19 will change the art market forever. Sotheby's gained permission to become more digitized and to develop a more extended (and cost-saving) online marketplace. That does not mean that live, in-person auctions will disappear. Yet, they will likely become more hybridized as globally streamed drama. A profit-driven market that thrives on the allure of art as a financial asset has refracted the crisis-driven digital turn differently 
than the moral economy of the gallery market, even if trust relations and collective effervescence are important to both.

\section{Art markets, viruses, and viral markets}

How has the global pandemic affected the production, distribution, and consumption of contemporary art? In various corners of the art market, participants are rethinking how online connections can substitute for personal interaction and how social bonds are transformed by the absence of face-to-face communication. Those who produce, purchase, and sell art must confront how to maintain relationships of mutual trust and committed engagement with those whom they can no longer meet in person. Artists can still produce work, sometimes with adjustments to their practices, yet they can only exhibit their work on digital platforms. Collectors, in turn, can view artworks only on such platforms. Artists and collectors alike find them insufficient for fostering social connections and for aesthetically appreciating the physical qualities of artworks, even while some collectors value the increased transparency in prices. Collectors also miss the emotive experience of art world events: the collective effervescence that emerges from social interactions in the presence of "priceless" artworks (Velthuis 2005). Even dealers claim that they miss the emotionally and intellectually fulfilling experience of close relationships with artists.

Across social roles, participants report that they seek to maintain existing social ties, but the development of new ties has been limited. However, there are also noteworthy differences of the effects of COVID-19 between the primary and secondary market, partly mediated by their distinct market subcultures. The primary art market has suffered more from the problem of cultivating distant bonds and the lack of copresence with artworks. In the moral economy of this market segment, artists, dealers, and collectors routinely rely upon personal relationships of trust for their mutual engagement that are challenged by the COVID-19 online world. Dealers and collectors emphasize aesthetic value, making the magical aura of the work and its material qualities more important for sales. As a result, revenue has declined and online transactions remain more confined to existing networks of solidarity.

However, in the secondary auction market, prices are more transparent and economic speculation is accepted, given its more commercial approach. As a result, the secondary market has enjoyed a smoother transition to the crisis-driven expansion of digital platforms, even as auction houses struggle to re-create the drama and collective effervescence of in-person major auctions. The auction market is more likely to retain some of these newer modes of digital interaction, in conjunction with a resumption of in-person activities after the pandemic. A more bifurcated auction world could emerge, one with a vastly extended online market for most sales that allow for multiple buy-now initiatives and the more punctuated live auctions for the global super-rich that keep the business lucrative and maintain the brand's glamorous sheen.

The contemporary art world offers lessons for how other markets may be impacted by the COVID-19 crisis beyond purely economic ramifications. Markets that heavily rely upon developing informal relationships based on trust and that sell goods whose 
value rests on rarified and unique experiences rather than standardized metrics will likely face more tumult when moving their operations remotely. While some experiences can occur online or without physical co-presence, consumers often pay not only for the experiences themselves, but also for the affect and status derived from immersive consumption. For example, clients at elite nightclubs willingly pay exponentially higher prices for alcohol in order to feel excitement and gain status within the VIP global party circuit (Mears 2020). Finally, markets for unique goods whose qualities are difficult to appreciate remotely will likely face steep challenges. In the housing market, for instance, buyers almost exclusively place offers after in-person viewings and frequently change their evaluation after these viewings (Besbris 2020). A sociological analysis of the COVID-19 crisis emphasizes not only the economic, but also the social and cultural challenges as market participants adapt.

In composing a brief article in the white heat of crisis, we admit the limitations of temporality, particularly given the constraints on field research. Intellectual modesty is essential. As the crisis is still ongoing, we cannot definitely know what large-scale transformations will occur in the longer term. We acknowledge that this time has been marred by a second crisis of police violence. As most of our interviews were conducted before the surge in anti-racism protests, we do not address how this historic movement has impacted the art world in light of the content of work and the activities of art market participants. This essay is not the last word on the subject, nor should it be.

Acknowledgements All three authors contributed equally to the preparation of this article. We wish to thank Ulf Wuggenig and Michael Jauchen for their insightful feedback on sections of the article. We also would like to thank the auction specialists Suzy Sikorski as well as Xiaoming Zhang for enlightening extended conversations on the subject.

\section{References}

Alexander, J. 2004. Cultural Pragmatics: Social Performance Between Ritual and Strategy. Sociological Theory 22: 527-573.

Alexander, J. 2006. The Civil Sphere. New York: Oxford University Press.

Becker, H. 1982. Art Worlds. Berkeley: University of California Press.

Belcove, J. 2020. 16 Contemporary Artists Respond to the Covid-19 Crisis with Poignant New Works, Robb Report, April 10th. https://robbreport.com/shelter/art-collectibles/gallery/contemporaryartists-covid-19-new-works-2911980/mika/. Accessed 12 June 2020.

Besbris, M. 2020. Upsold: Real Estate Agents, Prices, and Neighborhood Inequality. Chicago: University of Chicago Press.

Bourdieu, P. 1993. The Field of Cultural Production. New York: Columbia University Press.

Cappellazzo, A. 2020. Contemporary Art Market in Extraordinary Times. JP Morgan Webcast. June 11.

Cappelletti, A., M. Gloria, and F. Meris. 2013. Meet the Dealer: Friedrich Petzel. The Collector Tribune, https://www.collectortribune.com/2013/03/07/meet-the-dealer-friedrich-petzel/. Accessed 10 May 2020.

Cohen, A. 2020. How Artists with Large Studios Are Supporting Their Assistants and Making New Work, Artsy, April 27th. https://www.artsy.net/article/artsy-editorial-artists-large-studios-suppo rting-assistants-making-new-work. Accessed 12 June 2020. 
Coslor, E. 2016. Transparency in an Opaque Market: Evaluative Frictions Between "Thick" Valuation and "Thin" Price Data in the Art Market. Accounting, Organizations and Society 50: 13-26.

Fillitz, T. 2014. The Booming Global Market of Contemporary Art. Focaal 69: 84-96.

Goffman, E. 1981. Forms of Talk. Philadelphia: University of Pennsylvania Press.

Halperin, J. 2020. The Good News? Global Online Auctions Grew 63 Percent Last Month. The Bad News? That May Not Be Nearly Enough. Artnet News, April 22, https://news.artnet.com/market/ online-auctions-march-data-1841205. Accessed 22 May 2020.

Herrero, M. 2010. Auctions, Rituals and Emotions in the Art Market. Thesis Eleven 103: 97-107.

Hiscox. 2019. Hiscox Online Art Trade Report 2019. https://www.hiscox.co.uk/sites/uk/files/docum ents/2019-04/hiscox-online-art-trade-report--2019.pdf. Accessed 22 June 2020

Horowitz, N. 2012. Internet and Commerce. In Contemporary Art and Its Commercial Markets: A Report on Current Conditions and Future Scenarios, ed. Maria Lind and Olav Velthuis, 85-114. Berlin: Sternberg Press.

Karpik, L. 2010. Valuing the Unique: The Economics of Singularities. Princeton: Princeton University Press.

Khaire, M. 2015. Art without borders? Online Firms and the Global Art Market. In Cosmopolitan Canvases: The Globalization of Markets for Contemporary Art, ed. Olaf Velthuis and Stafano Curioni, 102-128. New York: Oxford University Press.

Kinsella, E. 2020. Just How Bad Has the Financial Fallout Been for US Galleries? A New Survey Crunches the Numbers-and They're Bleak. Artnet News, May 19, https://news.artnet.com/ market/new-survey-financial-fallout-galleries-1864281?utm_content=from_. Accessed 23 May 2020.

Lee, K. 2018. Neoliberal Marketization of Global Contemporary Visual Art Worlds: Changes in Valuations and the Scope of Local and Global Markets. Art and the Challenge of Markets, vol. 2, 65-97. New York: Palgrave Macmillan

Mears, A. 2020. Very Important People: Status and Beauty in the Global Party Circuit. Princeton: Princeton University Press.

Moulin, R. 1987. The French Art Market: A Sociological View, trans. Arthur Goldhammer: Rutgers University Press.

Pogrebin, R., S. Reyburn, and Z. Small. 2020. Auction Houses Postpone Live Sales and Pivot to Online, New York Times, April 19, https://www.nytimes.com/2020/04/19/arts/design/art-aucti on-houses-sales-coronavirus.html. Accessed 20 May 2020.

Saito, H. 2006. Reiterated Commemoration: Hiroshima as National Trauma. Sociological Theory 24: 353-376.

Smith, C. 1989. Auctions: The Social Construction of Value. New York: Free Press.

Sotheby's. 2020a. Sotheby's First-Ever Online Day Sale of Contemporary Art Achieves Record-Setting \$13.7 Million in New York. Press release (May 15).

Sotheby’s. 2020b. Sotheby’s Live Global Auction Event Achieves \$363.2 million and 93\% sold. Press release (June 30).

Spiegler, M. 2020. In Will the Market's Digital Pivot Continue Post-Pandemic? Webcast by Art Basel, June 11, https://www.youtube.com/watch?v=5Z12WG1GDWE. Accessed 18 June 2020.

Velthuis, O. 2005. Talking Prices: Symbolic Meanings of Prices on the Market for Contemporary Art. Princeton: Princeton University Press.

Velthuis, O., and C. Erica. 2012. The Financialization of Art. In The Oxford Handbook of the Sociology of Finance, ed. Karin Knorr Cetina and Alex Preda, 471-487. New York: Oxford University Press.

Publisher's Note Springer Nature remains neutral with regard to jurisdictional claims in published maps and institutional affiliations.

Larissa Buchholz is an Assistant Professor in the School of Communication at Northwestern University and holds a courtesy appointment in the Department of Sociology. Currently, she is a fellow at the Institute for Advanced Study at CEU. Her forthcoming book examines the emergence of a global field in the contemporary visual arts and the different ways in which artists become valued worldwide. A second book project compares different moments in the rise of new art patrons and collectors, in emerging 
marketplaces like China, parts of Latin America, and the Middle East, as a window into understanding cultural consumption in a global context.

Gary Alan Fine is the James E. Johnson Professor of Sociology at Northwestern. He is currently a visiting researcher at the Rusell Sage Foundation in New York. He is the author of Talking Art: The Culture of Practice and the Practice of Culture in MFA Education and Everyday Genius: Self-Taught Art and the Culture of Authenticity. His current research is an ethnography of senior citizen political activists.

Hannah Wohl is an Assistant Professor of Sociology at the University of California, Santa Barbara. She studies processes of judgment and valuation across creative industries. Her current book project, an ethnography of the New York contemporary art world, explores how artists create and circulate distinctive bodies of work. 